\title{
Education inclusive in partner-affective development: a study with students who present permanent special educational needs
}

\author{
Educación inclusiva en el desarrollo socio-afectivo: un estudio con \\ estudiantes que presentan necesidades educativas especiales permanentes
}

Lourdes Elizabeth Navas Franco. ${ }^{1}$, Oscar Gustavo Benalcázar Oñate. ${ }^{2}$ Mónica Narciza López Pazmiño. ${ }^{3} \&$ Jhon Patricio Acosta Bonilla. ${ }^{4}$

Recibido: 19-02-2019 / Revisado: 20-02-2019 /Aceptado: 27-03-2019/ Publicado: 04-04-2019

\begin{abstract}
.
DOI: https://doi.org/10.33262/cienciadigital.v9i2.390

Inclusive Education responds to a diversity of needs in learners, the aim is to achieve teacher participation during the process of teaching and learning, aiming to reduce socio-educational and social exclusion. The objective of the study was to determine the impact of inclusive teacher training on the socio-affective development of students with permanent special educational needs in the Juan Montalvo Educational Unit in the city of Ambato, Ecuador. An exploratory and descriptive field study was used; the sample consisted of 6 teachers to whom a structured interview was applied, while the 20 parents of students with permanent special educational needs were administered a structured questionnaire, which was validated by means of the cronbach alpha coefficient and the Kendall correlation coefficient; the data were analyzed by means of the statistical package
\end{abstract}

${ }^{1}$ Universidad Tecnológica Indoamérica, Facultad de Ciencias Humanas, de la Educación y desarrollo social, Carrera de Educación Básica e Inicial. Ambato, Ecuador. lourdesnavas@uti.edu.ec

${ }^{2}$ Ministerio de Inclusión Económica y Social. Ambato, Ecuador. Oscar.benalcazar@cz.inclusion.gob.ec

${ }^{3}$ Universidad Tecnológica Indoamérica, Facultad de Ciencias Humanas, de la Educación y desarrollo social, Carrera de Educación Básica e Inicial. Ambato, Ecuador. monicalopez@uti.edu.ec

${ }^{4}$ Universidad Tecnológica Indoamérica, Facultad de Ciencias Humanas, de la Educación y desarrollo social, Carrera de Educación Básica e Inicial. Ambato, Ecuador. jhonacosta@uti.edu.ec 
SPSS V25.0. It can be concluded that inclusive teacher training affected the socioaffective development of students with permanent special educational needs, considering that students through teacher-directed activities reinforce equal opportunities and participatory learning, while failure to receive the necessary attention will result in limitations in the development of physical, mental and psychoaffective capacities, which creates barriers to learning.

Keywords: Inclusive education, socio-affective development, permanent special educational needs

\section{Resumen.}

La Educación Inclusiva responde a una diversidad de necesidades en los educandos, el fin es alcanzar la participación docente durante el proceso de enseñanza aprendizaje, teniendo como fin reducir la exclusión socio-educativa y social. El objetivo del estudio fue determinar la incidencia de la capacitación docente inclusiva en el desarrollo socioafectivo de los estudiantes con necesidades educativas especiales permanentes de la Unidad Educativa Juan Montalvo de la ciudad de Ambato, Ecuador. Se empleó un estudio de campo de nivel exploratorio y descriptivo; la muestra estuvo integrada por 6 docentes a quienes se les aplicó una entrevista estructurada, mientras que a los 20 padres de familia de los estudiantes con necesidades educativas especiales permanentes se les administró un cuestionario estructurado, el cual fue validado mediante el coeficiente alfa de cronbach y por el coeficiente de correlación de Kendall, los datos se analizaron mediante el paquete estadístico SPSS V25.0. Se puede concluir que la capacitación docente inclusiva incidió en el desarrollo socio-afectivo de los estudiantes con necesidades educativas especiales permanentes, considerando que los estudiantes mediante las actividades dirigidas adecuadamente por el docente refuerzan la igualdad de oportunidades y el aprendizaje participativo, mientras que, al no recibir la atención necesaria se mantendrá limitaciones en el desarrollo de las capacidades físicas, mentales y psicoafectiva, lo cual genera barreras en el aprendizaje.

Palabras claves: Educación inclusiva, desarrollo socio-afectivo, necesidades educativas especiales permanentes.

\section{Introduction.}

The Educational Reform has generated countless questions where the Educational Integration of Children with Special Educational Needs (SEN) has been one of the most controversial issues, due to the variety of opinions held by the various entities responsible in the field of education. Alonso \& Nicasio (2014) affirm that Educational Integration refers to the union of different people for a joint work, having the teacher as a function to foster affectivity 
within different contexts to achieve the integral development of the learner that includes cognitive levels, procedures, behavior, attitudes, the practice of values (López, 2017).

Teachers, by maintaining training to innovate their knowledge, strengthen the teaching of contents during the educational cycle; their goal is to foster communicative, social, and intellectual skills in the educational environment; the subject presented has as a characteristic that no research or studies have been carried out in relation to the independent variable teacher training and the dependent variable socio-affective development in students with permanent special educational needs.

By analyzing the importance of the work of teachers within and outside the education system and their insertion into the school environment, the improvement of learning, capacities, and potentialities. Boto (2007) mentions that educational skills favor cooperative work where socialization, respect for human beings, and the fulfillment of duties and rights stand out; an institution that defines itself in its educational project as a school that attends to biological and cultural differences and where diversity is valued, and therefore each one of the students is responded to, regardless of their characteristics, must assume substantial changes in their educational culture.

According to Denmark (2013), the curriculum should be as broad, balanced and diverse as possible, capable of being adapted to the individual and socio-cultural needs of boys and girls, with an open and flexible teaching style both in its methodologies and in its activities that allow for the personalization of the experiences of apprentices and promote the greatest possible development, in relation to the integration and participation of all; deducing that the integrative approach favors empathy, improves learning situations, with the educational, family and social community assuming the commitment to reduce discriminatory forms and improve well-being.

Although the Ecuadorian education reform proposes the implementation of inclusive education projects and curricular adjustments, few schools have opted to work with integration to achieve inclusive education without taking into account the great demand that exists. For example, there is no integration between financial, curricular, and teacher training aspects. 
The child is the focus of intervention and it is he who needs to adapt, where the demands of school and the responsibility for his education falls mainly on specialists; there is a lack of continuity between the different cycles of the school system. This has meant that many children who have had the experience of being educated in the regular school, have to be incorporated for the first time in a special school or return to it, restricting their possibilities of an integrated life project.

The practice of integration is an action that represents a democratic society, in which future generations learn from an early age to relate and respect differences as a factor of enrichment and personal development. However, the slow application of the process means that this is a topic of recent significance, where the draft Organic Law on Intercultural Education, the integration of which has not yet been evaluated, makes it impossible to carry out an in-depth analysis of the experiences; According to Vega (2015) this objective can be achieved, the school has to achieve the difficult balance of offering an educational response, both comprehensive and diversified, providing a common curricular structure to all students, including those with special educational needs, that avoids discrimination and inequality of opportunities and at the same time takes into account their characteristics and individual needs.

According to Sánchez (2015), integration favors the performance of a person with Special Educational Needs; they are considered the same as others. This boosts their capacities and self-esteem, since they are valued for what they are and can deliver. An appropriate climate of respect is guaranteed, focused on the value of personnel and society; since contact between the human being and the environment produces the integration of people with and without special needs, it undergoes changes that can be registered at three levels that are determined by the characteristics of the people and the conditions of the environment, taking place within the family, school, community and work institution.

By using integrative evaluation approaches in the classroom, it is obtained that the training of the learner in an environment of safety and confidence strengthens the integration to an inclusive school. Vera (2015) mentions the importance of physical integration, which is 
understood as a spatial approach between people with and without special needs. They use the same resources and means; functional integration includes active participation and cooperation among learners to achieve learning goals; social integration: It refers to the social rapprochement between people with and without special needs, spontaneous interactions occur and affective bonds are established.

For Pascual (2015), autonomy is a concept that says that autonomy should flourish better in one's own personality and that one should be able to act with increasing capacity for autonomy, judgment and personal responsibility; Luque (2009) suggests that leaving behind the conception that education should focus on the transmission of specific disciplinary contents, positioning itself as a formal educational axis, the development of learning skills, to think about the contents of any area, taking advantage of the possibilities offered by education throughout life, starting from the activities of the student, that is, the contents are not conceived as ends, but as instruments at the service of natural evolutionary development. In the educational system, the principle is to achieve a sustained education in the practice of values, with the teacher guiding the socio-affective development through different activities carried out in the environment.

The ability to relate favors cooperation in solving conflicts, communicating ideas, desires, in a constructive way through reflection, awareness and appreciation; the development of socioaffective skills reduces limitations in learning, violence and anxiety; socio-affective education, based on pedagogical and psychological contributions, strengthens intelligences, knowledge of one's own emotions and those of others in order to achieve social competence and improve relations with the environment.

Núñez, Amieiro, Álvarez, García, \& Dobarro (2015) add that self-regulation, which favors in the impulse control to favor in the self-control (the handling) of emotions; self-esteem and confidence (achievement of goals and objectives) and self-motivation, favors in motivation, commitment and affective social development.

Lorenzo (2014) points out that the affective dimension, which is related to feelings and motivations as opposed to learning, self-concept, self-esteem and valuing one's own 
competence; the relational dimension that is evidenced in the type and quality of relationships between teachers and students, type and quality of relationships with peers, and expectations; and finally the conditions of disability, which are manifested in sensory, physical or mental deficiencies; It can be deduced that the current educational system has not been able to respond to the totality of students with permanent special educational needs that they possess since the rigidity in the structure implies a homogenization with respect to the curriculum, to evaluation, starting from the physical structure, which is clearly not prepared for children with some deficiency to develop each cognitive process. Experience has shown that integration poses to the educational community as a whole the challenge of attention to diversity and, therefore, interventions must be made at the level of the entire educational context. For these reasons, the study aims to determine the impact of inclusive education on the socio-affective development of students with permanent special educational needs at the Juan Montalvo Educational Unit in the city of Ambato, Ecuador.

\section{Methodology.}

In the basic research modality, the study was carried out in the field at the Juan Montalvo Educational Unit in the city of Ambato, Ecuador. During the months of September and December 2017. A systematic analysis of reality was carried out with the intention of describing, interpreting, understanding and understanding the problem of the scarce inclusive teacher training and socio-affective development in students with permanent special educational needs, favoring the knowledge of causes and effects; the documentary study benefited in the establishment of criteria of diverse authors that allowed for comparison, broadening and deepening of the different approaches and concepts.

This research on the topic of inclusive teacher training and socio-affective development in students with permanent special educational needs is exploratory in nature, using a questionnaire that enabled the extraction of data. The descriptive type allowed orienting the prediction and identification of the relations that exist between the two variables; the explanatory level described the problem of the scarce inclusive teacher training and the socioaffective development in the students with permanent special educational needs, trying to explain the causes that gave origin to the analysis of the situation establishing the causes in 
different types of study, establishing conclusions and explanations to enrich or clarify the theories, confirming or not the initial thesis.

The sample worked with the entire population and consisted of 6 teachers and 20 parents of students with permanent special educational needs from the Juan Montalvo Educational Unit in the city of Ambato, Ecuador.

For this purpose, an interview was applied to the teachers with 8 structured questions and to look for qualitative results and analysis and a questionnaire to the parents of the students, the latter composed of 7 questions looking for nominal qualitative results and analysis with four possible answers that were quantified as follows: never 0 , sometimes 1 , almost always 2 and always 3; and thus to be able to determine the incidence of inclusive teacher training in the socio-affective development of the students.

The questionnaire to parents was validated by the research team, the validity of the content was determined through a consultation with experts (10), and the degree of concordance of their answers with the Kendall concordance coefficient (W), and the reliability of the instrument through its internal consistency, calculating the Cronbach Alfa coefficient (C).

All participants were explained in detail the objectives and procedures of the study and were provided with the information necessary for their knowledge. They expressed their verbal consent to participate in the research. Written consent was not obtained because it was an observational research that did not require an intervention and from the legal point of view according to the Helsinki Declaration it is not necessary that this consent be written; in addition to being a research project cited in the category of research without risk.

For statistical analysis, percentages and descriptive statistics were used and the statistical package SPSS 25.0 was used.

\section{Results.}

The degree of agreement among the experts (content validity) could be classified as acceptable while the reliability (internal consistency) was classified as good (table 1). 
Table 1. Validity and reliability of the Questionnaire applied to parents in general.

\begin{tabular}{|c|c|c|c|}
\hline Kendall W & Level & Level Cronbach Alfa & Level \\
\hline 0.74 & Acceptable & 0.83 & Good \\
\hline
\end{tabular}

Source Structured Parent Questionnaire and SPSS p $<0.01$

Source Prepared by a group of researchers.

Meanwhile, in the analysis and interpretation of the questionnaire applied to 20 parents (students with permanent special educational needs), the results were as follows (tables 2 and 3):

In Question 1: Do you think that teacher-led activities promote equal opportunities and participation in learning? It is considered that the teacher does not demonstrate a positive attitude towards diversity, which harms the development of children's capacities; while a smaller percentage mentions that the teacher does strengthen the quality of his or her pedagogical work.

Question 2: In learning spaces, does the teacher strengthen equality, equity, and respect for student rights through school work? It is deduced that the teacher does not attend to the learning community, and there is little application of methodologies and strategies to reduce school failure; while a minority state that the teacher does promote quality education for all students.

In question 3: Do you consider that the teacher, through the planning and organization of tasks, helps the student in the resolution of conflicts, communication and interaction? It is determined that the majority of teachers do not make plans or work plans to strengthen children's knowledge; while a minority mentions that the teacher, through modifications in methodology, forms of evaluation, and teaching of contents, attends to individual differences among students.

In question 4: Do you believe that the teacher by organizing content, implementing strategies and guiding your child in the process of teaching learning? It follows that most teachers do not carry out knowledge reinforcement activities in the areas required by the learner; a minority do select content teaching strategies and evaluation criteria.

In question 5: Do you consider that the educator in the learning process makes curricular and methodological adaptations according to the needs and capacities of your child? It is analyzed that teachers do not carry out curricular and methodological adaptations, which harms autonomy, interaction and communication, generating difficulties in access to certain concepts, affecting classroom experience and work.

In question 6: Do you believe that the teacher motivates your child's learning, demonstrates confidence, creativity, dialogues and listens to his ideas and needs? It is established that the teacher does not strengthen emotional education, which limits the development of affective competencies, damaging balance, expression, self-confidence and self-confidence. 
In question 7: Do you believe that the teacher through tasks strengthens in your child the practice of values of honesty, respect, responsibility and cooperation among peers? It follows that teachers do not support dedication, effort and coexistence, generating obstacles in interpersonal relations and coexistence, having repercussions in the development of emotional competencies, learning and performance.

As can be seen in tables 2 and 3, the highest levels of response are in questions 1, 2, 3 and 6; and the lowest levels are in questions 7 and 4.

Table 2. Analysis of the application of the questionnaire applied to parents of students.

\begin{tabular}{|c|c|c|}
\hline Question & $\mathbf{X}$ & SD \\
\hline $\mathbf{1}$ & 1.8 & .42 \\
\hline $\mathbf{2}$ & 1.9 & .31 \\
\hline $\mathbf{3}$ & 2.1 & .38 \\
\hline $\mathbf{4}$ & 1.3 & .34 \\
\hline $\mathbf{5}$ & 1.6 & .47 \\
\hline $\mathbf{6}$ & 1.7 & .29 \\
\hline $\mathbf{7}$ & 1.2 & .33 \\
\hline $\mathbf{X}$ & $\mathbf{1 . 7}$ & $\mathbf{. 3 5}$ \\
\hline
\end{tabular}

Source Structured Parent Questionnaire $\mathrm{p}<0.01$

Source Prepared by a group of researchers.

Table 3. Analysis of parental responses

\begin{tabular}{|c|c|c|c|c|c|c|c|c|}
\hline Question & Never & \% & Sometimes & $\boldsymbol{\%}$ & Almost Always & $\boldsymbol{\%}$ & Always & $\boldsymbol{\%}$ \\
\hline 1 & 9 & 45 & 4 & 20 & 6 & 30 & 1 & 5 \\
\hline 2 & 9 & 45 & 4 & 20 & 7 & 35 & 0 & 0 \\
\hline 3 & 8 & 40 & 3 & 15 & 8 & 40 & 1 & 5 \\
\hline 4 & 12 & 60 & 3 & 15 & 5 & 25 & 0 & 0 \\
\hline 5 & 10 & 50 & 5 & 25 & 5 & 25 & 0 & 0 \\
\hline 6 & 9 & 45 & 3 & 15 & 7 & 35 & 1 & 5 \\
\hline 7 & 12 & 60 & 4 & 20 & 4 & 20 & 0 & 0 \\
\hline
\end{tabular}

Source Structured Parent Questionnaire

Source Prepared by a group of researchers.

\section{Discussion}

Through the pedagogical and didactic work, the teacher carries out activities designed to reinforce equal opportunities. This is how the importance of stimulating physical, mental and psycho-affective abilities and achieving academic goals is known; while a minority does have opportunities. 
Sarrionandia (2015) mentions that the application of activities, jobs and tasks is required to consolidate responsibilities and commitments in learning, developing communicative skills, interpersonal relations, exploration and acquisition of significant knowledge that favors thinking and creativity.

Learners through curricular adaptations made by the teacher strengthen communication having the same opportunities to participate in the process of coexistence; for Lopez (2015), students with permanent special educational needs through education sustained in the curriculum strengthen independence, and the development of potentialities; According to the criteria of Olivencia and Gerdel (2017), students with permanent special educational needs, sometimes in the educational environment due to the inadequate application of innovative methodologies demonstrate insecurity, damaging emotional development, teamwork, impacting on the development of values such as respect and solidarity.

The scarce development of social skills harms interaction with peers, the environment and the family, self-confidence and the establishment of affective ties with the people of the environment for Chamorro and López (2013) the teacher plans and executes activities that stimulate the participation of the father of the family in making educational decisions regarding his children.

Teachers use activities that integrate the family as a basic component for advancing learning, contributing to a positive and collaborative relationship.

Alulima and Solís (2013) state that parents contribute to their children's learning in order to provide opportunities for learning and development; it follows that the lack of parental support is a factor that conditions communication and continuity in school life.

The support received by the learner in the environment favours learning and interaction. According to Calero (2014), the scarce externalization of concerns harms the processes of intervention and active participation, the use of inclusive techniques to improve integration; however, the affectivity that the student with permanent special educational needs receives from the environment strengthens teamwork, promotes respect, attention and motivation to improve academic performance, dialogue, understanding and learning.

According to Jara, González and Toledo (2016), students with permanent special educational needs do not receive motivations and incentives, show mistrust, insecurity and low selfesteem, show irresponsibility in the learning process, do not comply with school tasks, which affects academic performance, requiring reinforcement in respectful attitudes that help them behave and develop positively in the environment to improve skills and competencies.

In a study conducted Vlez (2013) the results show that the facets proposed in the phrase map to evaluate attitudes: attitude measurement, educational agents and scenarios, and didactic 
elements, were confirmed by the SSA analysis. In general, teachers in training show positive attitudes towards inclusive education. It is also identified that the participants visualize the teacher as the central educational agent of inclusive education and consider that in order to carry it out, it is indispensable to have resources or specialized materials for the work in the classroom and institutional support for its attainment and the qualification of teachers.

According to González (2015), Special Education professionals receive initial training as teachers in infant or primary education, and specialization is acquired through training in qualifying mentions. The current university training itinerary proposes a new conceptual framework that includes priorities oriented towards a new perspective and vision of these specializations within the training generated as teachers, with an updated and innovative character. This professionalization in inclusive education poses a special education teaching challenge, using a methodology based on innovative practices and experiences, shared in the ordinary classroom, favoring the acquisition of new skills. As can be observed, in most of the cases above.

\section{Conclusions.}

- Inclusive teacher training affects the socio-affective development of students with permanent special educational needs, considering that the student, through the activities designated by the teacher, reinforces equal opportunities and participates in learning; otherwise, not receiving the necessary attention, he or she will maintain limitations in the development of physical, mental and psycho-affective capacities, generating barriers to learning, emotional and social competencies.

- When analyzing the level of inclusive teacher training on permanent special educational needs, it can be deduced that the teacher has not received updates in the pedagogical and didactic area. Most teachers do not apply methodologies and strategies to reduce school failure; nor do they plan and organize tasks that help resolve conflicts, improve communication and interaction. No strategies are applied to guide the process of teaching and learning; no curricular and methodological adaptations are made according to the needs and capacities of the learners. 


\section{References.}

Alonso, J., \& Nicasio, J. (2014). Actitudes de los maestros hacia la integración escolar de niños con necesidades especiales. Journal for the Study of Education and Development , 10.

Alulima, L., \& Solis López, D. (2013). derechos de protección a estudiantes con Necesidades Educativas Especiales. Quito, Pichincha, Ecuador: Universidad Tecnológica Indoamérica.

Boto, N. (2007). La Atención Educativa en niños, niñas y jóvenes considerados con necesidades educativas especiales. Ecuador: Universidad Javeriana.

Calero, G. (2014). Desarrollo socio afectivo. Bogotá, Colombia: universidad Javeriana.

Chamorro, B., \& López, M. (2013). Integración de niños con Necesidades Educativas Especiales. Ambato, Tungurahua, Ecuador: Universidad Técnica de Ambato.

Denmark, J. (2103). Formación del profesorado par la edcuación inclusiva. European Agency for development in Special Needs Education, 23.

González A (2015). Formación del profesorado de educación inclusiva: reto docente de la educación especial. Opción, 31 (3): 582 - 604

Jara, M., González, D., \& Toledo, V. (2016). Estudio Comparativo de las Habilidades Socioafectivas Desde el Humanismo, entre un establecimiento convencional y no convencional. Santiago, Chile: Universidad Academia de Humanismo Cristiano Escuela de Psicología.

López Pazmiño, M. N. (2017). Intervención psicopedagógica en el refuerzo académico mediante técnicas y estrategias para el fortalecimiento de las funciones psicológicas superiores en las Fundaciones Don Bosco, Santa Marianita, Proyecto Salesiano y el Gobierno Autónomo Descentralizado. Ambato, Ecuador: Universidad Técnica de Ambato. Programa de Vinculación con la Sociedad N. 5. Planificación, evaluación y desarrollo de métodos para la enseñanza y superación personal.

López Pazmiño, M. N., \& Inga Loja, L. (2015). Gestión de Proyectos (Fcaultad de Cienvcias Humnanas y de la Educación). Ambato, Tungurahua, Ecuador: Universidad Técnica de Ambato.

Lorenzo, R. (2014). Procesos cognitivos básicos relacionados con la lectura. Redalyc, 45. Luque, D. (2009). Las necesidades educativas especiales como necesidades básicas. Una reflexión sobre la inclusión educativa. Revista Latinoamericana, 25. 
Núñez, J., Amieiro, N., Álvarez, D., García, T., \& Dobarro, A. (2015). Escala de evaluación de la autorregulación del aprendizaje a partir de textos. European Journal of Education and Psychology, 8(1), 1-22.

Olivencia, J., \& Gerdel, M. (2017). La educación inclusiva como constructo pedagógico en el alumnado universitario de educación primaria. Revista de Educación Inclusiva, $8(2), 8$.

Pascual, R. (2015). Desarrollo de la Autonomía Personal en la Educación Primaria aplicada al alumno con discapacidad intelectual leve. Valladolid: Universidad de Valladolid.

Sánchez, L. (2015). El desarrollo socio - afectivo y su influencia en la atención en niños de 4 a 5 años de la Unidad Educativa "dos de marzo" del cantón Antonio Ante, Provincia de Imbabura, en el año 2014-2015. Ibarra: Universidad Técnica del Norte.

Sarrionandia, G. (2015). Competencias esenciales en la formación inicial de un profesorado inclusivo. Un proyecto de la Agencia Europea para el desarrollo de las necesidades educativas especiales. Tendencias pedagógicas, 19, 7-24.

Vega, A. (2015). Integración de alumnas con Necesidades Edcuativas Especiales. Chile: Universidad de Chile.

Vélez Libia (2013). La educación inclusiva en docentes en formación: su evaluación a partir de la teoría de facetas. Folios. Segunda época. 37: 95-113

Vera, D. (2015). Recursos didácticos para estudiantes con necesidades educativas especiales. La Libertad, Ecuador: Universidad Estatal Península de Santa Elena.

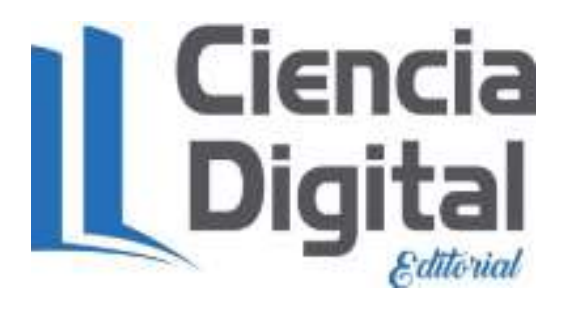




\section{Para citar el artículo indexado.}

Navas L., Benalcázar O., López M. \& Acosta J (2019). Education inclusive in partneraffective development: a study with students who present permanent special educational needs. Revista electrónica Ciencia Digital 3(2), 275-288. Recuperado desde: http://cienciadigital.org/revistacienciadigital2/index.php/CienciaDigital/article/view/390/838

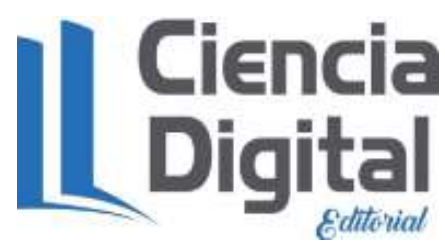

El artículo que se publica es de exclusiva responsabilidad de los autores y no necesariamente reflejan el pensamiento de la Revista Ciencia Digital.

El artículo queda en propiedad de la revista y, por tanto, su publicación parcial y/o total en otro medio tiene que ser autorizado por el director de la Revista Ciencia Digital.
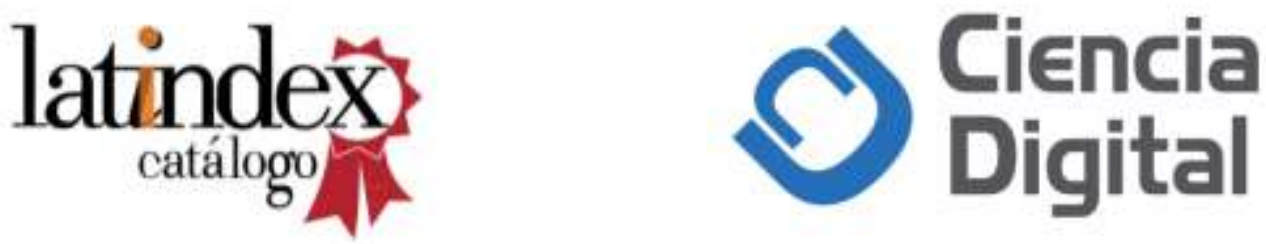